\title{
Parotid Gland Mucoepidermoid
}

\section{Carcinoma}

National Cancer Institute

\section{Source}

National Cancer Institute. Parotid Gland Mucoepidermoid Carcinoma. NCI Thesaurus.

Code C5938.

A carcinoma that arises from the parotid gland. It usually presents as a firm and painless mass. It is characterized by the presence of epidermoid cells, mucus producing cells, and cells of intermediate type. It usually spreads to pre-auricular lymph nodes. The majority of cases have a favorable outcome. 